\title{
Chemical Composition and Antioxidant Properties of Wild Tunisian Edible and Medicinal Mushrooms
}

\author{
Rim Ben Mansour*, Sarra Dakhlaoui, Riadh Ksouri, Wided Megdiche-Ksouri. \\ Laboratory ofAromatic and Medicinal Plants, Center of Biotechnology, Technopark of Borj-Cedria (CBBC), BP \\ 901, 2050 Hammam-Lif, Tunisia.
}

*Corresponding Author: Rim Ben Mansour, Laboratory ofAromatic and Medicinal Plants, Center of Biotechnology, Technopark of Borj-Cedria (CBBC), BP 901, 2050 Hammam-Lif, Tunisia.

\begin{abstract}
Wild medicinal mushrooms have been considered as therapeutic agents since long in Asian countries, but their use in Tunisia has been slightly increased only since the last few years. This study is, to our knowledge, the first to investigate the richness of four wild Tunisian edible and medicinal species of basidiomycetes (Tricholoma terreum, Tricholoma equestre, Ganoderma lucidum and Agaricus campestris) on phenolics, fatty acids and to evaluate their antioxidant properties via 5 in vitro tests. Significant differences were observed in phenolic contents and antioxidant capacities between species. G. Lucidum extract exhibited the highest phenolic and flavonoid contents (18.7 mg EAG/g DW and $5.3 \mathrm{mg} C E / g \mathrm{DW}$ ) related to the important total antioxidant capacity $(5.4 \mathrm{mg} E A G / \mathrm{g} \mathrm{DW}), D P P H\left(I C_{50}=0.14 \mathrm{mg} / \mathrm{mL}\right)$, ABTS $\left(I C_{50}=0.98\right.$ $\mathrm{mg} / \mathrm{mL})$ and $\beta$-carotene bleaching tests $\left(I C_{50}=0.26 \mathrm{mg} / \mathrm{mL}\right)$, respectively. Fatty acids profiles of these species were carried out by chromatography. High levels of unsaturated fatty acids (79.5-84.2 \%) were observed in all species, which gives them an important nutritional value. The dominant fatty acid was linoleic acid followed by the oleic acid. Percentage of these two compounds varied from $40 \%$ to $60.2 \%$ and $16.65 \%$ to $37.17 \%$ respectively.
\end{abstract}

Keywords : antioxidant activities, wild edible mushrooms, GC-MS, fatty acids, chemical composition.

\section{INTRODUCTION}

Edible and medicinal higher fungi have been used by humankind for millennia. They are collected and used directly not only for their nutritional values as a main source of food or as a part of regular diet but also for their medicinal purpose as source of powerful new bioactive compounds. Many, if not all, Basidiomycetes mushrooms (BMs) contain biologically active compounds in fruit bodies, cultured mycelium and culture broth (Wasser, 2011). They had long been used as a folk remedy for promotion of health and longevity in many oriental countries for their important chemical and nutritional characteristics (Kalac, 2012). Actually, BMs are clinically confirmed and constitute a strong base for intensive research and development of basidiomycetes biologically active metabolites (BAMs) such as organic acids, alkaloids, terpenoids, steroids and phenolics (Kim and Kim, 1999; Prasad et al., 2015). BMs are also valuable health food, high in vitamins, minerals, fibers, and nutritive compounds such as protein, essential amino acids and polyunsaturated fatty acids. Numerous species of wild growing mushrooms are widely consumed as a delicacy in Tunisia. For instance, Ganoderma lucidum (Reishi), Agaricus campestris (Agaricaceae), Tricholoma terreum and Tricholoma equestre are appreciated mushrooms due to their organoleptic, nutritional and pharmacological properties (Yilmaz et al., 2006). Several studies have reported a number health benefits of these species, such as antioxidant, anti-aging (Cherian et al., 2009; Kosanić et al., 2017), antimicrobial (Karwa et al., 2012), hypoglycemic (Xiao et al., 2012), antiulcer (Gao et al., 2004) and anti-inflammatory (Muszyńska et al., 2018) effects. Polysaccharides, essential fatty acids and secondary bioactive compounds are the best known and potent mushroom-derived substances with high values (Chen et al., 2012; Gąsecka et al. 2017). These properties, along with low cytotoxicity, raise the possibility that it could be effective in the cancer patients receiving conventional chemotherapy and/or radiation treatment, to build up immune resistance and decrease toxicity (Bishop et al., 2015). For instance, previous data have demonstrated that G. lucidum polysaccharides stimulated immune function both in vivo and in vitro (Wang et al., 2000). A. campestris extracts were 
also found to possess good antitumor activities (Li et al., 2005; Kosanić et al., 2017). Water extract of this specie enhances the secretion of insulin and have insulin like effects on glucose metabolism (Gray and Flott, 1998).

In Tunisia, few chemical investigations were reported concerning T. terreum, T.equestre, G. lucidum and $A$. campestris. Therefore, the aim of this study was to provide some insight into the chemical composition as well as the antioxidant capability of extracts obtained from these wild mushrooms.

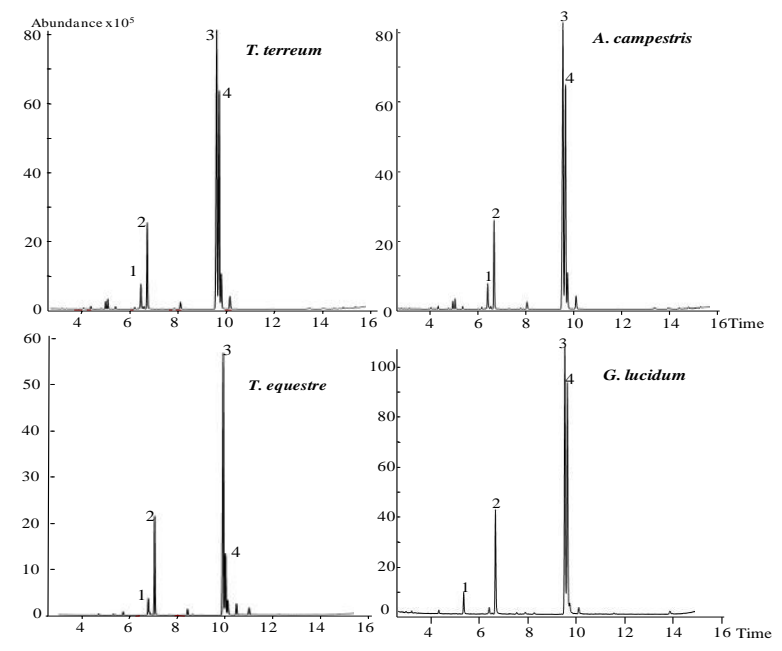

Fig1. Profils of the major fatty acid composition of mushroom species: 1. palmitoleic acid, 2. palmitic acid, 3. linoleic acid 4. oleic acid.

\section{Materials AND Methods}

\subsection{Fungal Materials and Extraction}

Specimens of Tricholoma terrum, Tricholoma equestre, Ganoderma lucidum and Agaricus campestris L, were collected from Tunisian mountainous Kroumerie region $\left(36^{\circ} 34^{\prime} 60^{\prime \prime}\right.$ N, $8^{\circ} 25^{\prime} 0^{\prime \prime}$ E; $600 \mathrm{~km}$ west Tunis; humid bioclimatic stage; mean annual rainfall $>1000 \mathrm{~mm}$ ) in December 2016 and identified at the Sylvo-Pastoral Institute of Tabarka. The harvested specimens were rinsed with distilled water, then oven-dried at $37^{\circ} \mathrm{C}$, and grinded to a fine powder. Extracts were obtained by magnetic stirring of $3 \mathrm{~g}$ of dry powder with $30 \mathrm{ml}$ of methanol at $80 \%$ for 2 hours. The obtained filtrate is evaporated using a rotary evaporator. Dry residue was then stored at $4^{\circ} \mathrm{C}$ until analysis.

\subsection{Total Phenol Content (TPC) Analysis}

Colorimetric quantification of total polyphenol was determined as described by Dewanto et al., 2002). Briefly, $125 \mu \mathrm{L}$ of suitable diluted sample extract was dissolved in $500 \mu \mathrm{L}$ of distilled water and 125 $\mu \mathrm{L}$ of the Folin-Ciocalteu reagent. The mixture was shaken before adding $1250 \mu \mathrm{L}$ sodium carbonate anhydrous $\left(\mathrm{Na}_{2} \mathrm{CO}_{3}\right)\left(70 \mathrm{~g} \mathrm{~L}^{-1}\right)$, then adjusted with distilled water to a final volume of $3 \mathrm{ml}$, and mixed thoroughly. After incubation for $90 \mathrm{~min}$ at $23^{\circ} \mathrm{C}$ in the dark, the absorbance versus prepared blank was read at $760 \mathrm{~nm}$ (LABOMED, INC. UV/Vis apparatus). TPC of mushroom was expressed as $\mathrm{mg}$ gallic acid equivalents per gram of dry weight $\left(\mathrm{mg} \mathrm{GAE} \mathrm{g}^{-1} \mathrm{DW}\right)$ through the calibration curve with gallic acid ranging from 0 to $400 \mu \mathrm{g} \mathrm{mL} \mathrm{L}^{-1}\left(\mathrm{r}^{2}=0.99\right)$.

\subsection{Total Flavonoid Content (TFC) Analysis}

Total flavonoids were measured by colorimetric assay according to Dewanto et al. (2002). An aliquot of diluted sample or standard solution of (+)-catechin was added to a $75 \mu \mathrm{L}$ of sodium nitrite solution $\left(\mathrm{NaNO}_{2}\right)$, and mixed for $6 \mathrm{~min}$ before adding $0.15 \mathrm{ml}$ of aluminum chloride hexahydrate solution $\left(\mathrm{AlCl}_{3}, 6 \mathrm{H}_{2} \mathrm{O}\right)\left(100 \mathrm{~g} \mathrm{~L}^{-1}\right)$. After $5 \mathrm{~min}, 0.5 \mathrm{~mL}$ of sodium hydroxide $\mathrm{NaOH}(1 \mathrm{M})$ was added and the final volume was adjusted to $2.5 \mathrm{~mL}$ with distilled water and then mixed. Absorbance was determined at $510 \mathrm{~nm}$ against the same mixture, without the sample, as a blank. Total flavonoid content was expressed as milligram catechin equivalent per gram dry weight $\left(\mathrm{mg} \mathrm{CE} \cdot \mathrm{g}^{-1} \mathrm{DW}\right)$, through the calibration curve of $(+)$-catechin ranging from 0 to $400 \mu \mathrm{g} \mathrm{mL}^{-1}\left(\mathrm{r}^{2}=0.99\right)$.

\subsection{Total Soluble Carbohydrate Contents}

The content of total soluble carbohydrates in the studied samples was determined according to Staub (1963), using glucose as a standard. Briefly, $25 \mathrm{mg}$ of sample was homogenized with $5 \mathrm{ml}$ methanol $80 \%$ and boiled while shaking at $70^{\circ} \mathrm{C}$ for $30 \mathrm{~min}$ and then centrifuged. An aliquot of $250 \mu \mathrm{l}$ was added to $5 \mathrm{ml}$ of anthrone-sulfuric acid solution. The mixture was shaken, heated in a boiling water- 
bath for $10 \mathrm{~min}$ and cooled at $4{ }^{\circ} \mathrm{C}$. The absorption was determined by spectrophotometry (Anthelie Advanced 2, SECOMAN) at $640 \mathrm{~nm}$. A standard curve was prepared using different concentration of glucose $(0-100 \mu \mathrm{g}$, from MERCK KGaA). From the standard curve, the concentrations of soluble carbohydrates in the test samples were calculated $(y=0.0095 x-0.0299, R 2=0.979)$.

\subsection{Fatty Acid Methyl Ester Analysis (FAMEs)}

Mushroom powder $(1 \mathrm{~g})$ was mixed with $6 \mathrm{ml}$ of hexane and $0.5 \mathrm{~mL}$ of $\mathrm{NaOH}(0.2 \mathrm{~N})$ dissolved in ethanol. After shaking, the lower phase was removed and the fatty acids (FA) present in the upper fraction were converted to methyl esters with $3 \mathrm{~mL}$ of a Boron trifluoride-methanol complex (14\%) reagent, and incubated at $60^{\circ} \mathrm{C}$ for $15 \mathrm{~min}$. The fatty acid methyl ester was washed with $2 \mathrm{ml}$ of water and extracted with $10 \mathrm{~mL}$ of petroleum ether. The identification of FAMEs was performed by GC-MS using an HP-5980 Series II instrument, equipped with HP-5MS capillary column (30 m x $0.25 \mathrm{~mm}$; $0.25 \mu \mathrm{m}$ film thickness), split/splitless injector $\left(220^{\circ} \mathrm{C}\right)$. The oven temperature was held at $150^{\circ} \mathrm{C}$, then programmed at $15^{\circ} \mathrm{C} / \min$ up to $220^{\circ} \mathrm{C}$, and held isothermally at $220^{\circ} \mathrm{C}$ for 5 min. Helium was the carrier gas at an initial flow rate of $1 \mathrm{ml} / \mathrm{min}$. Split ratio was 20:1. Injection volume was $2 \mu \mathrm{l}$. Quantification of FA methyl esters, expressed as percentage, was obtained directly from GC-MS peak area integration. The components were identified by comparing their relative retention times and mass spectra with the data from the Wiley library, Mass-Finder and Adams GC/MS library.

\subsection{Evaluation of Total Antioxidant Capacity (TAC)}

The assay is based on the reduction of Mo (VI) to Mo (V) by the extract and subsequent formation of a green phosphate/Mo $(\mathrm{V})$ complex at acid $\mathrm{pH}$. An aliquot $(0.1 \mathrm{~mL})$ of mushroom extract was combined to $1 \mathrm{~mL}$ of reagent solution $(0.6 \mathrm{M}$ sulfuric acid, $28 \mathrm{mM}$ sodium phosphate and $4 \mathrm{mM}$ ammonium molybdate), then incubated in a thermal block at $95^{\circ} \mathrm{C}$ for $90 \mathrm{~min}$. After the mixture had cooled to room temperature, the absorbance of each solution was measured at $695 \mathrm{~nm}$ against a blank. The antioxidant capacity was expressed as mg GAE.g-1 DW (Koleva et al., 2002). The calibration curve range was $0-500 \mu \mathrm{g} \mathrm{mL}-1$.

\subsection{Scavenging Effect on DPPH and ABTS Radicals}

DPPH quenching ability of extracts was measured according to Hanato et al. (1988). $1 \mathrm{~mL}$ of the samples was added to $250 \mu \mathrm{L}$ of $0.2 \mathrm{mM}$ solution of DPPH. After $30 \mathrm{~min}$ of incubation at room temperature, the absorbance was read against a blank at $517 \mathrm{~nm}$.

The ABTS radical-scavenging activity of extracts was determined according to Re et al. (1999). $\mathrm{ABTS}^{+}$cation radical was produced by the reaction between $5 \mu \mathrm{L}$ of $14 \mathrm{mM} \mathrm{ABTS}{ }^{+}$solution and $5 \mu \mathrm{L}$ of $4.9 \mathrm{mM}$ potassium persulfate solution, and stored in the dark at room temperature for 16 hours. Prior to use, this solution was diluted with ethanol to get an absorbance of $0.700 \pm 0.020$ at $734 \mathrm{~nm}$. In a final volume of $1 \mathrm{~mL}$, the reaction mixture comprised $950 \mu \mathrm{L}$ of $\mathrm{ABTS}^{+}$solution and $50 \mathrm{~mL}$ of the mushroom extract at various concentrations $\left(20-200 \mathrm{mg} \mathrm{mL}^{-1}\right)$. The reaction mixture was homogenized and its absorbance was recorded at $734 \mathrm{~nm}$. Methanol blanks were run in each assay, and all measurements were done after a minimum of 6 minutes. Similarly, the reaction mixture of the standard group was obtained by mixing $950 \mu \mathrm{L}$ of $\mathrm{ABTS}^{+}$solution and $50 \mu \mathrm{L}$ of BHT.

DPPH and $\mathrm{ABTS}^{+}$scavenging ability were expressed as $\mathrm{IC}_{50}\left(\mathrm{mg} \mathrm{mL}^{-1}\right)$ which is the Inhibiting Concentration of $50 \%$ of the synthetic radical. The inhibition percentage (IP \%) of DPPH and $\mathrm{ABTS}^{+}$ radicals was calculated using the following formula:

$\operatorname{IP}(\%)=\left[\left(\mathrm{A}_{0}-\mathrm{A}_{1}\right) / \mathrm{A}_{0}\right] \times 100$

where $\mathrm{A}_{0}$ and $\mathrm{A}_{1}$ are the absorbance of the control and the sample, respectively.

\subsection{B-Carotene Bleaching Test (BCBT)}

A modification of the method described by Koleva et al. (2002) was employed. $\beta$-Carotene ( $2 \mathrm{mg}$ ) was dissolved in $20 \mathrm{~mL}$ chloroform. $4 \mathrm{ml}$ of this solution was mixed with $40 \mathrm{mg}$ linoleic acid and 400 $\mathrm{mg}$ Tween 40. Chloroform was evaporated under vacuum at $40^{\circ} \mathrm{C}$ and $100 \mathrm{ml}$ of oxygenated ultrapure water was added, then the emulsion was vigorously shaken. An aliquot of $150 \mu \mathrm{L}$ of the $\beta$ carotene/linoleic acid emulsion was distributed in the 96 wells of the microtitre plates and solutions of the test samples $(10 \mu \mathrm{L})$ were added. Three replicates were prepared for each sample. The microtitre plates were incubated at $50^{\circ} \mathrm{C}$ for $120 \mathrm{~min}$, and the absorbance was measured using a model EAR 400 microtitre reader (Labsystems Multiskan MS) at $470 \mathrm{~nm}$. Readings of all samples were performed immediately ( $\mathrm{t}=0 \mathrm{~min}$ ) and after $120 \mathrm{~min}$ of incubation. The antioxidant activity of the extracts was evaluated in terms of blanching inhibition of the $\beta$-carotene the following formula 
$\beta$-Carotene bleaching inhibition $(\%)=[(\mathrm{S}-\mathrm{C} 120) /(\mathrm{C} 0-\mathrm{C} 120)] / 100$

Where $\mathrm{C} 0$ and $\mathrm{C} 120$ are the absorbance values of the control at 0 and $120 \mathrm{~min}$, respectively, and $\mathrm{S}$ is the sample absorbance at $120 \mathrm{~min}$. The results were expressed as IC50 values $(\mu \mathrm{g} / \mathrm{ml})$.

\subsection{Chelating Effects on Ferrous Ions}

The ferrous ion chelating activity of wild mushroom extracts was assessed as described by Zhao et al. (2006). Different concentrations of mushroom extracts were added to to a solution of $2 \mathrm{mM} \mathrm{FeCl} 2$ $(0.05 \mathrm{ml})$.The reaction was initiated by adding $100 \mu \mathrm{l}$ of ferrozine $(5 \mathrm{mM})$ and adjusted to $3 \mathrm{ml}$ with distilled water, shaken vigorously, and left standing at room temperature for $10 \mathrm{~min}$. Absorbance of the solution was then measured spectrophotometrically at $562 \mathrm{~nm}$. The percentage of inhibition of ferrozine-Fe2+ complex was calculated using the formula (1). Results were expressed as EC50: efficient concentration corresponding to $50 \%$ ferrous iron chelating.

\subsection{Statistical Analysis}

The statistical analysis was carried out using the IBM SPSS Statistics 22 software. Each mean value is accompanied by the standard error (mean $\pm \mathrm{SE}$ ). The results were compared using the ANOVA (single-criterion) analysis, based on the smallest significant difference at the 5\% threshold. Multiple comparisons were made using the Tukey HSD test (Honestly Significantly Difference).

\section{RESULTS AND DISCUSSION}

\subsection{Chemical Composition and Analysis}

Phenolic acids and flavonoids are important compounds with scavenging ability due to their hydroxyl groups and hence may contribute directly to the antioxidative action. The amount of total phenolics (TP) and flavonoids (TF) in wild BMs varied significantly from 0.84 to $18.68 \mathrm{mg}$ GAE/g DW and 0.08 to $5.29 \mathrm{CE} / \mathrm{g} \mathrm{DW}$, respectively (Table 1 ). The highest amount of $\mathrm{TP}$ and $\mathrm{TF}$ was found in $G$. lucidum with a value of $18.7 \mathrm{mg}$ EAG/g DW and $5.3 \mathrm{mg} \mathrm{CE} / \mathrm{g}$ DW respectively. T. terreum and $A$. campestris showed the lowest TP (0.84 mg EAG/g DW) and flavonoids ( $0.09 \mathrm{mg}$ CE/g DW) contents, respectively. The level of phenolics in wild BMs are somewhat comparable with the other reports. Numerous studies on mushrooms reported total phenolics ranging from 0.83 to $42.21 \mathrm{mg} \mathrm{GAE} / \mathrm{g}$ of extract (Wong and Chye, 2009), 2.09 to $10.51 \mathrm{mg} \mathrm{GAE} / \mathrm{g}$ of extract (Gursoy et al., 2010) and 3.39$14.6 \mathrm{mg} \mathrm{GAE} / \mathrm{g}$ of extract (Woldegiorgis et al., 2014). Besides, BMs flavonoids contents are in agreement with total phenolic ones. Several works reported that the chemical composition and antioxidant activity varied in BMs (Mishra et al., 2013). This diversity is depending on the strain, to the environmental factors and the geographic origin.

Total sugars are a flavor compounds contained in the mushroom contributing to the sweet taste (Litchfield, 1967). Therefore, the high content of sugars would adduce rise the moderate sweet taste perception (Beluhan and Ranogajec, 2011). The sugar content of studied wild edible mushroom species in this work are shown in Table 1 . Values were ranged from 39 to $58 \mathrm{mg} / 100 \mathrm{~g} \mathrm{DW}$. The highest total sugar content was found in G. lucidum $(58 \mathrm{mg} / 100 \mathrm{~g})$ which is in agreement with results found by Colak et al. (2007) who found $50.10 \mathrm{~g} / 100 \mathrm{~g}$ of proteins. Jedidi et al (2016) reported level of total sugar in Tunisian A. campestris was $47.7 \pm 0.29 \mathrm{~g} \mathrm{~kg}^{-1} \mathrm{DW}$ which is also similar to our results. In the same context, Barros et al. (2008a) reported a higher protein content ranged between 47 and $80 \mathrm{~g} / 100 \mathrm{~g}$ for some mushroom species.

Table1.

\begin{tabular}{|c|c|c|c|}
\hline Samples of mushrooms & $\begin{array}{c}\text { Total phenolics } \\
(\mathrm{mg} \mathrm{GAE} / \mathrm{g} \mathrm{DW})\end{array}$ & $\begin{array}{c}\text { Total flavonoids } \\
(\mathrm{mg} \mathrm{CE} / \mathrm{g} \mathrm{DW})\end{array}$ & $\begin{array}{c}\text { Total soluble sugar } \\
(\mathrm{mg} / 100 \mathrm{~g} \mathrm{DW})\end{array}$ \\
\hline Tricholoma terreum & $0.840 \pm 0.2 \mathrm{c}$ & $0.264 \pm 0.03 \mathrm{~b}$ & $50.05 \pm 0.7 \mathrm{~b}$ \\
\hline Agaricus campestris & $1.698 \pm 0.4 \mathrm{~b}$ & $0.088 \pm 0.01 \mathrm{c}$ & $39.21 \pm 0.4 \mathrm{~cd}$ \\
\hline Tricholoma equestre & $1.457 \pm 0.4 \mathrm{~b}$ & $0.125 \pm 0.01 \mathrm{~b}$ & $40.88 \pm 0.5 \mathrm{c}$ \\
\hline Ganoderma lucidum & $18.688 \pm 1.1 \mathrm{a}$ & $5.297 \pm 1.1 \mathrm{a}$ & $58.25 \pm 1.1 \mathrm{a}$ \\
\hline
\end{tabular}

\subsection{Antioxidant Activity of Extracts}

The extracts of tested mushrooms showed high total antioxidant capacity (Table 2). Overall the assays, G. lucidum had better antioxidant properties with high TAC and lower $\mathrm{IC}_{50}$ values.

Table 2 showed the strong TAC was found in G. lucidum extract (5.4 mg EAG/g DW) than $T$. equestre (131.77 mg EAG/g DW) followed by A. campesrtis ( $0.95 \mathrm{mg}$ EAG/g DW) and at the end $T$. terreum (59.83 mg EAG/g DW). 
For the scavenging DPPH and ABTS radicals, G. lucidum presented the strongest DPPH and ABTS radical-scavenging activities ( $\mathrm{IC}_{50}=0,14$ and $0.98 \mathrm{mg} / \mathrm{mL}$ respectively), while $A$. campestris presented the lowest $\mathrm{IC}_{50}=3.33$ for the DPPH test and $T$. equestre the lowest $\mathrm{IC}_{50}$ value $2.58 \mathrm{mg} / \mathrm{mL}$ for the ABTS test. Kosanic et al. (2017) showed A. campestris extract had moderate free radical scavenging activity $\left(\mathrm{IC}_{50}=179.65 \mu \mathrm{g} / \mathrm{mL}\right)$. A study conducted by Barros et al. (2008b), showed Agaricus sp. mushrooms proved to have antioxidant activity, namely radical scavenging activity with $\mathrm{IC}_{50}$ ranged between 5.37 and $15.85 \mathrm{mg} / \mathrm{ml}$. Smina et al. (2011), revealed the potent antioxidant power of Ganoderma triterpenes, which were highly effective in scavenging most of the free radicals in vitro including $\mathrm{DPPH}^{+}$and $\mathrm{ABTS}^{+}$. That's why, Boonsong et al. (2016) reported that from many reasons, mushrooms are advised to be a natural and good source of antioxidants which play a crucial role for chemoprevention of many diseases caused by free radicals (Kamra and Bhatt, 2012). Besides, mushrooms contain various polyphenolic compounds recognized as an excellent antioxidant due to their ability to scavenge free radicals by single-electron transfer (Hirano et al., 2001).

The effect of mushroom extracts on the auto-oxidation of polyunsaturated fatty acids was evaluated using the $\beta$-carotene bleaching test. In that system, $\beta$-carotene as a target molecule was exposed to free radicals formed by linoleic acid oxidation in the presence of a free radical scavenger mushroom extract constituents. Results concerning $\beta$-carotene bleaching test, showed similar interpretation as previous tests (Table 2). G. lucidum extract exhibited high inhibition of linoleic acid oxidation $\left(\mathrm{IC}_{50}=\right.$ $0.26 \mathrm{mg} \mathrm{mL}^{-1}$ ). While, A. campestris and T. equestre showed an $\mathrm{IC}_{50}=2.04$ and $1.2 \mathrm{mg} \mathrm{mL}^{-1}$ respectively. In this research, $\mathrm{IC}_{50}$ values of the $\beta$-carotene bleaching test were comprised between 0.26 and $2.4 \mathrm{mg} \mathrm{ml}^{-1}$, thus reflecting humble antioxidant effects when compared with other medicinal mushrooms (Smina et al., 2011; Yang et al., 2002; Cheung et al., 2003). Also, the bleaching power may indicate potential antioxidant properties of tested mushrooms. Based on these results, the tested mushrooms appear to be good natural antioxidant, antimicrobial and anticancer agents. The identification of the active antioxidant, antimicrobial and anticancer compounds of these mushroom species can lead to their potential commercial usage in medicine, food production and the cosmetic industry. The presence of different antioxidants can hinder the extent of $\beta$-carotene-bleaching by neutralizing the linoleate-free radical and other free radicals formed in the system (Jayaprakasha $e t$ al., 2001).

On the other hand, the chealating power of T. equestre, A. campestris and T. terreum extracts were weak $\left(\mathrm{IC}_{50}=7,2.01\right.$ and $1.4 \mathrm{mg} / \mathrm{ml}$ respectively), while G. lucidum extract registred no activity (Table 2). Testing chelating ability on ferrous ions, extract from G. lucidum showed no chelating ability which is on the contrary with regard to other reports, Kozarski et al. (2011), showed $\mathrm{EC}_{50}$ value of the chelating ability on ferrous ions for G. lucidum extract was $0.59 \mathrm{mg} / \mathrm{mL}$. The absence of the chealating power test in G. lucidum extract can be explained by the relationship between the test specificity and the kind of antioxidants needed. This is why we can suggest that the chelating activity against the ferrous ion in G. lucidum can be related to specific phenolic compounds rather than their whole concentration (Jallali et al., 2014).

At the whole, our results displayed that phenolic contents are positively concomitant with the assessed antioxidant tests, except the chelating power test in mashroom extracts, suggesting this way that phenolic compounds are responsible for their antioxidant activity. In many reports has been found a high correlation between phenolic content and antioxidative activities. Phenolics are potential antioxidants which can donate hydrogen to free radicals and thereby stop the chain reaction of lipid oxidation at the initial stage, due to the presence of their phenolic hydroxyl groups (Kosanic et al., 2017).

Although, it is difficult to compare all obtained results with those reported in literature because the few information related $T$. equestre and T. terreum.

Table2. Antioxidant activities of mushroom methanolic extracts.

\begin{tabular}{|c|c|c|c|c|}
\hline \multirow{2}{*}{} & \multicolumn{3}{|c|}{ Samples of mushrooms } & \\
\cline { 2 - 5 } & G. lucidum & A. campestris & T. terreum & T. equestre \\
\hline TAC (mg AGE/g DW) & $540 \pm 0.05 \mathrm{a}$ & $95.55 \pm 0.05 \mathrm{~b}$ & $59.83 \pm 0.004 \mathrm{c}$ & $131.77 \pm 0.004 \mathrm{~b}$ \\
\hline $\begin{array}{c}\text { Antiradical activity } \\
\text { DPPH (mg/ml) }\end{array}$ & $0.14 \pm 0.01 \mathrm{a}$ & $3.33 \pm 0.09 \mathrm{c}$ & $1.42 \pm 0.01 \mathrm{~b}$ & $1.53 \pm 0.01 \mathrm{~b}$ \\
\hline
\end{tabular}




\begin{tabular}{|c|c|c|c|c|}
\hline $\begin{array}{l}\text { Antiradical activity ABTS } \\
\text { (mg/ml) }\end{array}$ & $0.98 \pm 0.04 b$ & $2.58 \pm 0.07 \mathrm{a} \mathrm{b}$ & $1.66 \pm 0.01 \mathrm{c}$ & $4 \pm 0.01 c$ \\
\hline Chelating power $(\mathrm{mg} / \mathrm{ml})$ & $\mathrm{Nd}$ & $2.01 \pm 1.14$ & $1.4 \pm 0.06 \mathrm{c}$ & $7 \pm 1.25$ \\
\hline $\begin{array}{c}\beta \text {-carotene bleaching } \\
(\mathrm{mg} / \mathrm{ml})\end{array}$ & $0.26 \pm 0.005 b$ & $2.04 \pm 0.015 \mathrm{a}$ & $\mathrm{Nd}$ & $1.2 \pm 0.011 \mathrm{a}$ \\
\hline
\end{tabular}

\subsection{Fatty Acids Analysis}

The fatty acid profiles of mushrooms are shown in Table 3. Ten saturated (SFA), monounsaturated (MUFA) and polyunsaturated (PUFA) fatty acids were identified. The main saturated fatty acid of mushroom lipids was found to be palmitic acid (C16:0), the main monounsaturated was oleic acid $(\mathrm{C} 18: 1 \omega-9)$ and the main polyunsaturated fatty acid was linoleic acid (C18:2 $\omega-6)$. Percentages of palmitic $(\mathrm{C} 16: 0)$, oleic $(\mathrm{C} 18: 1 \omega-9)$ and linoleic $(\mathrm{C} 18: 2 \omega-6)$ acid varied greatly depending on the mushroom type (Kavishree et al., 2008).

The major fatty acids identified for G. lucidum were the linoleic $(40.05 \%)$ and oleic $(36.35 \%)$ acids, for A.campestris, linoleic (42.58 \%) and oleic (37.17\%) acids, for T. equestre, linoleic (60.2\%) and palmitic (17.68\%) acids, for T. terreum, linoleic (41.3\%) and oleic (36.92\%) acids. In mushrooms, the fat content is interesting, thus, our results were comparable to those of Bilal et al. (2010) who reported the fats present in mushroom are dominated by unsaturated fatty acids. The above findings were in agreement with the results reported for other basidiomycetes, Yilmaz et al. (2006) and Pedneault et al. (2006) reported that fat fraction in mushrooms is mainly composed of UFA. Linoleic acid which is found as major fatty acid in A campestris (42\%) was previously found in other Agaricus species from many countries (Yilmaz et al., 2006). Hugaes (1962) observed that mushrooms are rich in linoleic acid which is an essential FA. The main fatty acids found in the studied mushrooms, linoleic and oleic acids, are common in eukaryotic organisms such as fungi. Otherwise, palmitic acid is common to different organisms. Linoleic acid is an essential fatty acid to mammals, and therefore, could be supplied in their diet through mushrooms. It is precursor of arachidonic acid and of prostaglandins biosynthesis, which play important physiologic activities. Oleic and linoleic acids were also reported as main fatty acids in A. campestris from Turkey (Yilmaz et al., 2006).

In this study, other fatty acids are present at only low levels such palmitic and stearic acids. These acids may exist in their free form or be conjugated to other lipid constituents. Byrne and Byrne (1975) have reported on levels of palmitic, stearic and oleic acids in the free form, and Stancher et al. (1992) expanded the observed range of free and bound fatty acids to include $\mathrm{C}_{8}$ and $\mathrm{C}_{13}-\mathrm{C}_{17}$ odd-numbered acids.

Concerning the sums of the fatty acids $\Sigma$ PUFA occurred in the highest percentage followed by $\Sigma$ SFA and $\Sigma$ MUFA. Mushrooms total lipids characterized by high unsaturated/saturated (UFA/SFA), $\omega-6 / \omega-$ 3 and linoleic:oleic acids ratios (Table 3). Thus, UFA accounted from 79.43 to $84.26 \%$ of total FA, depending on the solvent and the method of extraction used, corresponding to ratio of UFA/SFA accounted from 3.89 to 5.52. This result was in agreement with the observations reported for many species of basidiomycetes belonging to the families Agaricaceae, Amanitaceae, Boletaceae, Coprinaceae, Ganodermataceae and Tricholomataceae, stating that UFA predominated over SFA in total FA content (Yilmaz et al. 2006; Pedneault et al. 2007; Kavishree et al. 2008; Ribeiro et al. 2009; Papaspyridi et al. 2013; Sinanoglou et al., 2015).

The linoleic:oleic acid ratio accounted from 1.10 to 3.61 (Table 3) was lower than those reported by Sinanoglou et al. (2015) for L. sulphureus, lower also than those reported by Kavishree et al. (2008) for $C$. cibarius, $C$. clavatus, G. arinarius, $R$. brevepis, $S$. crispa, $T$. microcarpus and $T$. tylerance, by Barros et al. (2007) for L. deliciosus, L. giganteus, S. imbricatus and T. portentosum and by Barros et al. (2008a) for B. edulis, C. cornucopioides and M. oreades and higher than those reported by Kavishree et al. (2008) for L. squarrulosus and by Barros et al. (2008a) for A. bisporus, A. Silvaticus, A. Silvicola, C. gambosa and C. cibarius. Kavishree et al. (2008) reported that the linoleic:oleic acid ratio could be considered as a marker for the discrimination between species of the same mushroom genus. Indeed, Erkkil et al. (2008) reported that replacement of SFA with PUFA and MUFA in the diet can decrease cardiovascular risk, the high MUFA:SFA $(\geq 0.98)$ and PUFA:SFA $(\geq 2.22)$ ratios presented in mushrooms could make these mushrooms desirables from consumers, as far as nutrition is concerned. 
Table3. Compounds detected by GC-MS in Mushroom species

\begin{tabular}{|c|c|c|c|c|}
\hline \multirow[t]{2}{*}{ Compounds } & \multicolumn{4}{|c|}{ Mushroom species (Peak area \%) } \\
\hline & T. terreum & A. campestris & T. equestre & G. lucidum \\
\hline \multicolumn{5}{|l|}{ Saturated fatty acid } \\
\hline Tridecanoic acid $\left(\mathrm{C}_{13} \mathrm{H}_{26} \mathrm{O}_{2}\right)$ & 0.28 & 0.18 & - & 0.52 \\
\hline Myristic acid $\left(\mathrm{C}_{14} \mathrm{H}_{28} \mathrm{O}_{2}\right)$ & - & 2.37 & - & - \\
\hline Pentadecanoic acid $\left(\mathrm{C}_{15} \mathrm{H}_{30} \mathrm{O}_{2}\right)$ & 1.97 & 0.28 & 0.78 & 2.65 \\
\hline Palmitic acid $\left(\mathrm{C}_{16} \mathrm{H}_{32} \mathrm{O}_{2}\right)$ & 12.36 & 10.35 & 17.68 & 13.77 \\
\hline Stearic acid $\left(\mathrm{C}_{18} \mathrm{H}_{36} \mathrm{O}_{2}\right)$ & 2.63 & 1.95 & 2.19 & 1.04 \\
\hline Arachidic acid $\left(\mathrm{C}_{20} \mathrm{H}_{40} \mathrm{O}_{2}\right)$ & 0.19 & 0.12 & 0.04 & - \\
\hline \multicolumn{5}{|l|}{ Unsaturated fatty acid } \\
\hline Palmitoleic acid $\left(\mathrm{C}_{16} \mathrm{H}_{30} \mathrm{O}_{2}\right)$ & 4.13 & 4.51 & 3.8 & 1.0 \\
\hline Linoleic acid $\left(\mathrm{C}_{18} \mathrm{H}_{32} \mathrm{O}_{2}\right)$ & 41.3 & 42.58 & 60.2 & 40.05 \\
\hline Oleic acid $\left(\mathrm{C}_{18} \mathrm{H}_{34} \mathrm{O}_{2}\right)$ & 36.92 & 37.17 & 16.65 & 36.35 \\
\hline Petroselinic acid $\left(\mathrm{C}_{18} \mathrm{H}_{34} \mathrm{O}_{2}\right)$ & - & - & - & 2.03 \\
\hline \multicolumn{5}{|l|}{ Alcanes } \\
\hline Tetracosane $\left(\mathrm{C}_{24} \mathrm{H}_{50}\right)$ & - & - & - & 2.55 \\
\hline Cyclohexane $\left(\mathrm{C}_{14} \mathrm{H}_{26}\right)$ & 0.13 & 0.26 & - & - \\
\hline$\sum$ SFA & 17.43 & 15.25 & 20.69 & 17.98 \\
\hline$\Sigma$ MUFA & 41.05 & 41.68 & 20.45 & 39.38 \\
\hline$\Sigma$ PUFA & 41.3 & 42.58 & 60.2 & 40.05 \\
\hline PUFA/SFA & 2.36 & 2.79 & 2.9 & 2.22 \\
\hline MUFA/SFA & 2.35 & 2.73 & 0.98 & 2.19 \\
\hline UFA/SFA & 4.72 & 5.52 & 3.89 & 4.41 \\
\hline $\mathrm{C} 18: 2 \omega-6 / \mathrm{C} 18: 1 \omega-9$ & 1.11 & 1.14 & 3.61 & 1.10 \\
\hline
\end{tabular}

\section{CONCLUSION}

The aim of our study was to investigate the antioxidant activities of wild medicinal Tunisian mushroom extracts. To the best of our knowledge, this is the first report evaluating the biological activity of extracts from Tunisian mushrooms. The total phenol content is higher in G. lucidum extract. The results indicate that mushrooms are rich in total phenolic compounds with strong DPPH and ABTS free radicals scavenging activities. They present a novel potential source of innovative biomedical molecules.

\section{ACKNOWLEDGEMENT}

This work was supported by the Tunisian Ministry of Higher Education and Scientific Research (LR10CBBC06).

\section{REFERENCES}

[1] Barros, L., Baptista, P., Estevinho, LM., Correia, DM., Casal, S., Oliveira, B., Ferreira, ICFR., 2007. Fatty acid and sugar compositions, and nutritional value of five wild edible mushrooms from Northeast Portugal. Food Chem 105: 140-145.

[2] Barros, L., Cruz, T., Baptista P., Estevinho., LM, Ferreira, ICFR., 2008a. Wild and commercial mushrooms as source of nutrients and nutraceuticals. Food Chem Toxicol 46: 2742-2747

[3] Barros, L., Falcão, S., Baptista, P., Freire, C., Vilas-Boas, M., Ferreira, I.C.F.R., 2008b. Antioxidant activity of Agaricus sp. mushrooms by chemical, biochemical and electrochemical assays. Food Chemistry 111: 61-66.

[4] Beluhan, S and Ranogajec, A., 2011. Chemical composition and non-volatile components of Croatian wild edible mushrooms. Food Chemistry 124 (3): 1076-1082.

[5] Bilal, A.W., Bodha, R.H., Wani, A.H., 2010. Nutritional and medicinal importance of mushrooms. Journal of Medicinal Plants Research 4(24): 2598-2604,

[6] Bishop, KS., Kao, CH., Xu Y., Glucina, MP., Paterson, RR., Ferguson, LR., 2015. From 2000 years of Ganoderma lucidum to recent developments in nutraceuticals. Phytochemistry 114: 56-65.

[7] Boonsong, S., Klaypradit, W., Wilaipun, P., 2016. Antioxidant activities of extracts from five edible mushrooms using different solvents. Agr. Nat. Res 50: 89-97.

[8] Byrne, P.F.S and Brennan, P.J., 1975. Lipids of Agaricus bisporus. Journal of General Microbiology 89: 245-255.

[9] Chen, Y., Xie, M., Zhang, H., Wang, Y., Nie, S., Li, C., 2012. Quantification of total polysaccharides and triterpenoids in Ganoderma lucidum and Ganoderma atrum by near in-frared spectroscopy and chemometrics, Food Chem 135: 268-275. 
[10] Cherian, E., Sudheesh, N.P., Janardhanan, K.K., Patani, G., 2009. Free radical scavenging and mitochondrial antioxidant activities of Reishi-Ganoderma lucidum (Curt: Fr) P. Karst and ArogyapachaTrichopus zeylanicus Gaertn extracts, J. Basic Clin. Physiol. Pharmacol. 20: 289-308.

[11] Cheung, LM., Cheung, P.C.K., Ooi, V.E.C., 2003. Antioxidant activity and total phenolics of edible mushroom extracts. Food Chemistry 81: 249-255.

[12] Colak, A., Kolcuoglu, Y., Sesli, E., and Dalman, O., 2007. Biochemical composition of some Turkish fungi. Asian Journal of Chemistry 19: 2193-2199.

[13] Dewanto, V., Wu, X., Adom, KK., Liu, RH., 2002. Thermal processing enhances the nutritional value of tomatoes by increasing total antioxidant activity.J. Agriculture and Food Chemistry, 50 (10): 3010-3014.

[14] Erkkil, A., deMello, VDF., Risérus, U., Laaksonen, DE., 2008. Dietary fatty acids and cardiovascular disease: An epidemiological approach. Prog Lipid Res 47: 172-187.

[15] Gao, Y., Tang, W., Gao, H., Chan, E., Lan, J., Zhou, S., 2004. Ganoderma lucidum polysaccharide fractions accelerate healing of acetic acid-induced ulcers in rats. J. Med. Food. 7: 417-421.

[16] Gąsecka, M., Magdziak, Z., Siwulski, M., Mleczek, M., 2017. Profile of phenolic and organic acids, antioxidant properties and ergosterol content in cultivated and wild growing species of Agaricus. Eur Food Res Technol. 244 (2): 259-268.

[17] Gray, A.M and Flott, P.R., 1998. Insulin-releasing and insulin-like activity of Agaricus campestris (mushroom). Journal of Endocrinology 157: 259-266

[18] Gursoy, N., Sarikurkcu, C., Tepe, B., Solak, M.H., 2010. Evaluation of antioxidant activities of 3 edible mushrooms: Ramaria flava (Schaef.: Fr.) Quél., Rhizopogon roseolus (Corda) T.M.Fries., and Russula delica Fr. Food Science and Biotechnology 19(3): 691-696.

[19] Hanato, T., Kagawa, H., Yasuhara, T., Okuda, T., 1988. Two new flavonoids and other constituents in licorice root: their relative astringency and radical scavenging effects. Chemical and Pharmaceutical Bulletin 36: 2090-2097.

[20] Hirano, R., Sasamoto, W., Matsumoto, A., Itakura, H., Igarashi, O., Kondo, K., 2001. Antioxidant ability of various flavonoids against DPPH radicals and LDL oxidation. Journal of Nutritional Science and Vitaminology (Tokyo) 47: 357-362.

[21] Hugaes, DH., 1962. Preliminary Characterization of the lipid constituents of the cultivated mushroom Agaricus campestris. Mush. Sci 5: 540-546.

[22] Jallali, I., Zaouali, Y., Missaoui, I., Smeoui, A., Abdelly, C., Ksouri, R., 2014. Variability of antioxidant and antibacterial effects of essential oils and acetonic extracts of two edible halophytes: Crithmum maritimum L. and Inula crithmö̈des L. Food Chem. 145: 1031-1038.

[23] Jayaprakasha, G.K., Singh, R.P., Sakariah, K.K., 2001. Antioxidant activity of grape seed (Vitis vinifera) extracts on peroxidation models in vitro. Food Chemistry 73: 285-290.

[24] Jedidi, K., Ayoub, I., Philipe, T., Bouzouita, N., 2016. Chemical composition and non-volatile components of three wild edible mushrooms collected from northwest Tunisia. Mediterranean Journal of Chemistry 5(3): 434-441.

[25] Kalac, P., 2009. Chemical composition and nutritional value of European species of wild growing mushrooms: A review. Food Chemistry 113: 9-16

[26] Kamra, A And Bhatt, A.B., 2012. Evaluation of antimicrobial and antioxidant activity of Ganoderma lucidum extracts against human pathogenic bacteria. Int. J. Phar. Pharmacol.Sci. 4 (2): 359-61.

[27] Karwa, A.S and Rai, M.K., 2012. Naturally occurring medicinal mushroom-derived antimicrobials: A case-study using Lingzhi or Reishi Ganoderma lucidum (W. Curt.: Fr.) P. Karst.(higher Basidiomycetes) Int. J. Med. Mushrooms 14: 481-490.

[28] Muszyńska, B., Grzywacz-Kisielewska, A., Kała, K., Gdula-Argasińsk, J., 2018. Anti-inflammatory properties of edible mushrooms: A review. Food Chemistry 243: 373-381.

[29] Kavishree, S., Hemavathy, J., Lokesh, BR., Shashirekha, MN., Rajarathnam, S., 2008. Fat and fatty acids of Indian edible mushrooms. Food Chem 106: 597-602

[30] Kim, J.H and Kim, Y.S., 1999. A Fibrinolytic Metalloprotease from the Fruiting Bodies of an Edible Mushroom, Armillariella mellea. Bioscience, Biotechnology, and Biochemistry. 63: 12: 2130-2136

[31] Koleva, I.I., van Beek, T.A., Linssen, J.P.H., de Groot, A., Evstatieva, L.N., 2002. Screening of Plant Extracts for Antioxidant Activity: a Comparative Study on Three Testing Methods Phytochem. Anal. 13: 8-17.

[32] Kosanić, M., Ranković, B., Rančić, A., Stanojković, T., 2017. Evaluation of metal contents and bioactivity of two edible mushrooms Agaricus campestris and Boletus edulis. Emirates Journal of Food and Agriculture. 29(2): 98-103.

[33] Kozarski, M., Klaus, A., Niksic, M., Jakovljevic, D., Helsper, J.P.F.G., Van Griensven, L.J.L.D., 2011. Antioxidative and immunomodulating activities of polysaccharide extracts of the medicinal mushrooms Agaricus bisporus, Agaricus brasiliensis, Ganoderma lucidum and Phellinus linteus. Food Chemistry 129: 1667-1675. 
[34] Li, S.G., Chen, Bi Y., 2005. Studies on antioxidative and antitumor activities for two wild edible fungi. Edible Fungi China. 3: 58-63.

[35] Litchfield, J.H., 1967. Morel mushroom mycelium as a food-flavoring material. Biotechnology And Bioengineering IX: 289-304.

[36] Mishra, K.K., Pal, R., ArunKumar, C., Chandrashekara, S.K., Jain, J.C., Bhatt., 2013. Antioxidant properties of different edible mushroom species and increased bioconversion efficiency of Pleurotus eryngii using locally available casing materials. Food Chemistry 138: 1557-1563.

[37] Papaspyridi, L.M., Sinanoglou, VJ., Strati, IF., Katapodis, P., Christakopoulos, P., 2013. Fatty acid profiles of Pleurotus ostreatus and Ganoderma australe grown naturally and in a batch bioreactor. Acta Alimentaria.42 (3): 328-337.

[38] Pedneault, K., Angers, P., Avis, T., Gosselin, A., Tweddel, RJ., 2007. Fatty acid profiles of polar and nonpolar lipids of Pleurotus ostreatus and P. cornucopiae var. 'citrino-pileatus' grown at different temperatures. Mycol Res 111: 1228-1234.

[39] Pedneault, KP., Gosselia, A., Tweddell, RJ., 2006. Fatty acid composition of lipids from mushrooms belonging to the family Boletaceae. Mycolog. Res. 110: 1179-1183.

[40] Prasad, S., Rathore, H., Sharma, S., Yadav, A.S., 2015. Medicinal Mushrooms as a Source of Novel Functional Food. Int. J. Food Sci. Nutr. Diet. 04: 221-225.

[41] Re, R., Pellegrini, N., Proteggente, A., Pannala, A., Yang, M, Rice-Evans, C., 1999. Antioxidant activity applying an improved ABTS radical cationdecolorization assay. Free Rad Biol Med. 26: 1231-1237.

[42] Ribeiro, B., Guedes De Pinho, P., Andrade, PB., Baptista, P., Valentão, P., 2009. Fatty acid composition of wild edible mushrooms species: A comparative study. Microchem J. 93: 29-35.

[43] Sinanoglou, V.J., Zoumpoulakis, P., Heropoulos, G., Proestos, C., Ćirić, A., Petrovic, J., Glamoclija, J., Sokovic, M., 2015. Lipid and fatty acid profile of the edible fungus Laetiporus sulphurous. Antifungal and antibacterial properties. J Food Sci Technol. 52(6): 3264-3272.

[44] Smina, TP., Mathew, J., Janardhanan, K.K., Devasagayam, T.P.A., 2011. Antioxidant activity and toxicity profile of total triterpenes isolated from Ganoderma lucidum (Fr.) P. Karst occurring in South India. Environmental toxicology and pharmacology 32: 438-446.

[45] Stancher, B., Procida, G., Calabrese, M., 1992. Characteristics of the most common mushrooms cultivated in Italy. IV. Lipids: Determination of the content of free and bound fatty acids. Industrie Alimentari. 31 : 744-750.

[46] Staub, AM., 1963. Extraction, identification et dosages des glucides dans les extraits d'organes et les corps bactériens, In: Masson et Compagnie (eds) Techniques de laboratoire (Tome 1 et 2), Paris. 1307-1366

[47] Wang, MY., Liu, Q., Che, QM., Lin, ZB., 2000. Effects of G lucidum triterpenoids on three animal liverinjury models. Acta Pharm Sin. 35: 326-9.

[48] Wasser, S.P., 2011. Current findings, future trends, and unsolved problems in studies of medicinal mushrooms. Appl Microbiol Biotechnol. 89: 1323-1332.

[49] Woldegiorgis, AZ., Abate, D., Haki, GD., Ziegler, GR., 2014. Antioxidant property of edible mushrooms collected from Ethiopia. Food Chemistry. 157: 30-36.

[50] Wong, J.Y and Chye, F.Y., 2009. Antioxidant properties of selected tropical wild edible mushrooms. Journal of Food Composition and Analysis. 22: 269-277.

[51] Xiao, C., Wu, Q-P., Cai, W., Tan, J-B., Yang, X-B., Zhang, J-M., 2012. Hypoglycemic effects of Ganoderma lucidum polysaccharides in type 2 diabetic mice. Arch. Pharma-cal Res. 35: 1793-1801.

[52] Yang, JH., Lin, HC., Mau, JL., 2002. Antioxidant properties of several commercial mushrooms. Food Chemistry. 77: 229-235.

[53] Yilmaz, NM., Solamaz, I., El mastas, M., 2006. Fatty acid composition in some wild edible mushrooms growing in the Middle Black region of Turkey. Food Chem. 99: 168-174.

[54] Zhao, H., Dong, J., Lu, J., Chen, J., Li Y., Shan, L., 2006. Effect of extraction solvent mixtures on antioxidant activity evaluation and their extraction capacity and selectivity for free phenolic compounds in Barely (Hordeum vulgare L.). Journal of Agricultural and Food Chemistry. 54: 7277-7286.

Citation: Rim Ben Mansour, et.al., (2019). Chemical Composition and Antioxidant Properties of Wild Tunisian Edible and Medicinal Mushrooms. International Journal of Medicinal Plants and Natural Products (IJMPNP), 5(2), pp.28-36. http://dx.doi.org/10.20431/2454-7999.0502004

Copyright: (C) 2019 Authors, this is an open-access article distributed under the terms of the Creative Commons Attribution License, which permits unrestricted use, distribution, and reproduction in any medium, provided the original author and source are credited. 